UDC 75.046(497.113 Zrenjanin)(091)

https://doi.org/10.18485/ms_zmslu.2021.49.8

Оригинални научни рад

Вања В. Стојковић*

\title{
ПИЈАРИСТИЧКА КАПЕЛА СВЕТОГ СТЕФАНА У ЗРЕЊАНИНУ: ИСТОРИЈА И СЛИКАРСТВО
}

САЖЕТАК: Овај рад се превасходно бави феноменолошком и формалном анализом ликовног програма пијаристичке гимназијске капеле у Бечкереку, данашњем 3рењанину. Капела је подигнута 1846. године, у склопу пијаристичке гимназије, у истористичко-класицистичком маниру. Отворена непосредно пре мађарско-српског конфликта 1848. године, капела је у времену револуције претрпела велика оштећења, јер је служила као магацин за муницију, војна болница и привремено седиште патријарха Рајачића. Оригинални изглед фасаде је нарушен, али је богат ликовни програм капеле очуван, те у великој мери кореспондира са актуелним средњоевропским тенденцијама друге половине XIX века. Сликарство Јожефа Виплера, Јозефа Лихтенегера, Јожефа Пешкија и Јозефа Гојгнера, сачувано у пијаристичкој капели, сведочи о заступљености идеја позноназаренске доктрине на простору Торонталске жупаније.

КљУЧНЕ РЕЧИ: пијаристи, религиозно сликарство, Јожеф Виплер, Јозеф Гојгнер, Јозеф Лихтенегер, Јожеф Пешки.

\section{Историјске околности}

Капела Светог Стефана Мађарског подигнута је 1846. године, као део комплекса пијаристичке гимназије у Бечкереку (Nagybecskerek), данашњем Зрењанину, који представља прву институцију под управом пијаристичког монашког реда у Банату (ЂукАновић 2015: 166). Монашки ред пијариста (Ordo scolarum piarum) озваничио је 1621. године свештеник Јосеф Калазанц (Joseph Calasanctius, 1557-1648) и то је први католички ред превасходно посвећен образовању деце (ШијАковић 1987: 112; DомЁNECH I MIRA 1998: 332). Пијаристичке школе похађала су деца различитих конфесија, националности и економског статуса, те је такав вид образовања веома погодовао разнородној демографији Хабзбуршке монархије. Овај модел религијске едукације показао се као веома успешан, па је средином XIX века постао доминантан образовни

\footnotetext{
* Универзитет у Београду, Филозофски факултет, stojkovicvvanja@gmail.com
} 
систем у Средњој Европи, махом заступљен на територији угарских земаља са центрима у Будимпешти, Кечкемету, Сегедину, Великој Кањижи и Темишвару (ЂукАновит 2015: 142).

Смештена у мултиетничкој средини Торонталске жупаније, управа пијаристичке гимназије имала је задатак да пружи образовање ученицима римокатоличке, православне, протестантске и јудаистичке конфесије. Као монашки ред фокусиран на пружање образовања најсиромашнијим слојевима друштва, пијаристи су руководили разгранатом мрежом школа по земљама тадашње Угарске. Чанадски бискуп Јожеф Лоновић (József Lonovics, 1779-1847), етаблирани црквени писац и члан Мађарске академије наука, био је спона између локалне бечкеречке управе и пијаристичког реда са седиштем у Сегедину (Поповић 1849: 2). Његовим посредством 1846. године омогућено је отварање Ниже пијаристичке гимназије, под окриљем свештеника др Јаноша Варадија и пијаристичког пастора Јожефа Грубера (József Gruber, 1788-1873), на позицији директора и ректора нове образовне установе (ЂукАновић 2015: 142; FERENC 2015: 19).

Историјат комплекса изузетно је динамичан, узимајући у обзир да је отворен непосредно пре мађарске револуције 1848. године (MILEKER 2011: 315; ЂукАнОВиЋ 2015: 62). Тензија између мађарског и српског становништва на простору јужне Угарске тињала је, и догађаји у Пешти под вођством револуционарне мађарске владе изазвали су ланчану реакцију у Бечкереку. На скупштини Жупаније 1848. године, прочитан је допис намесништва у ком је прокламована слобода штампе и успостављање народне мађарске војске. Саопштење је изазвало реакцију српског народа, након чега су паљене матичне књиге на мађарском језику и уклоњена је мађарска тробојка са бечкеречке градске куће. Проглашењем Српске Војводине 13. маја 1848. године у Сремским Карловцима мађарско-српски конфликт је продубљен, а Народна гарда је за главна упоришта одредила Бечкерек и Вршац (МикАвицА, ЛЕмАјић 2016: 417-474). У ратној клими, бечкеречка управа 10. јуна укида рад школа, а пијаристичка гимназија бива претворена у војну болницу. По српском освајању Великог Бечкерека, 12. јануара 1849. године, патријарх Јосиф Рајачић (1785-1861) долази у Бечкерек ради организације управе над Војводином. Тим поводом од 23. јануара до 3. априла одседа у пијаристичкој гимназији, те врши службу у капели Светог Стефана Мађарског (Поповић 1849: 2; MileKer 2011: 317-335). Грађевина је имала бројне функције у годинама револуције, служећи као магацин за муницију, војна болница и привремено седиште патријарха Јосифа Рајачића, те је у великој мери оштећена и обнављана у више етапа.

Комплекс гимназије подигнут је 1846. године у стилу класицизма, испрва као једнобродна, угаона грађевина (ЂукАновић 2015: 210). У архивској грађи се помиње градитељ Јанош Кирин (János Quirin), али није извесно да ли је он био идејни творац овог архитектонског решења. Крајем XIX века, зграда је имала централно постављену атику, са барокним одликама извијених линија и сведеним неороманичким украсом. Оригинална фасада је пиластрима била издељена на пет вертикалних поља од којих је средишњи део био наглашен надвишеним делом атике и прекидом поткровног венца. 


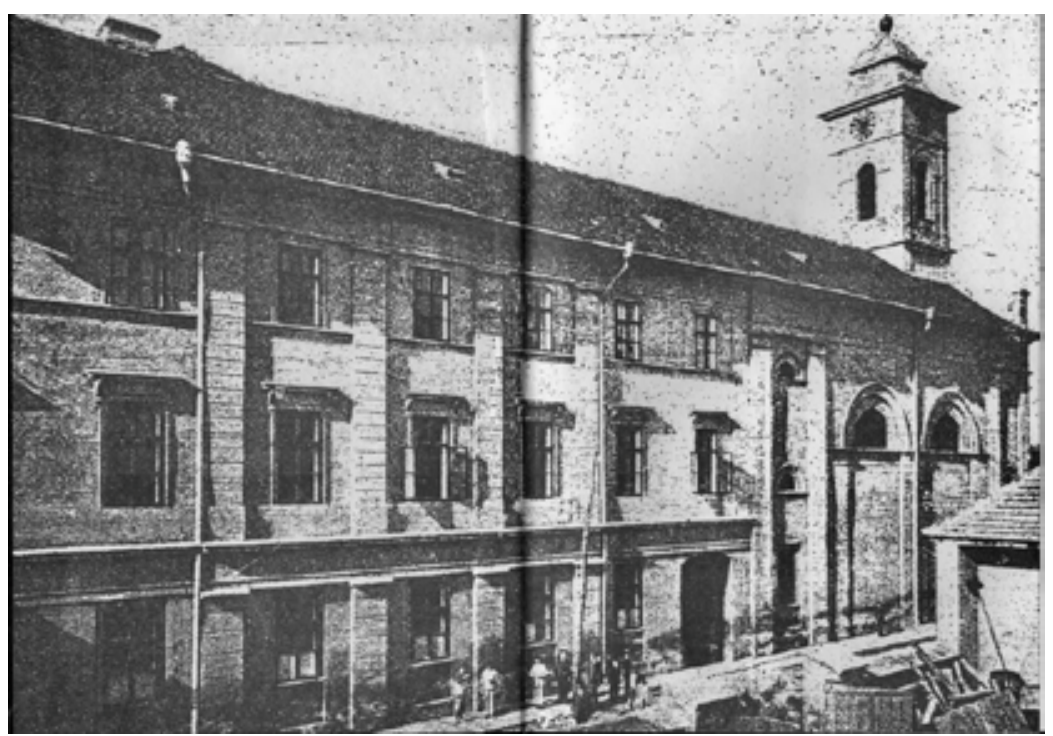

Сл. 1. Изглед уличне фасаде зграде гимназије крајем XIX века

Фасада је мењана у више наврата, те се само на основу архивске грађе закључује о оригиналном спољашњем изгледу здања (сл. 1) (БАКИЋ 2008: 47; FERENC 2015: 18).

Капела Светог Стефана је инкорпорирана у јединствену целину гимназијског комплекса, визуелно се издвајајући поделом фасаде и звоником. На равним фасадним површинама истичу се плитки пиластри који наглашавају звоник, и полукружни луци над прозорским отворима, односно слепим нишама. Прозори у виду полукруга постављени су високо, тако да су зидне површине доње зоне без отвора, осим два за улазна врата у зони звоника. Једноспратни торањ се уздиже из западне фасаде са прозорима на све четири стране. Капа звоника је пирамидалног облика са заобљеним врхом на коме су јабука и крст, а на којем је оригинално био постављен сат (БАКић 2004: 32; ЂукАнОвИЋ 2015: 376).

Првобитни изглед пијаристичке гимназије материјализација је истористичке реминисценције разних стилова (ТЕLESKO 2010: 11-38). Класицистичком формом, барокним одликама и неороманичким украсом саобразан је са средњоевропским градитељским тежњама друге половине XIX века. Канонски пример раноистористичке грађевине представља Црква Светог Јована Непомука у Бечу (Johann-Nepomuk-Kirche) (1846), са чијом унутрашњом расподелом, поделом фасаде и орнаментиком кореспондира изглед пијаристичке гимназијске капеле у Бечкереку (СтАнолловић 1938: 153).

Могуће угледање на Цркву Светог Јована Непомука упућује на распрострањеност идеја ревитализације историјских стилова, које кореспондирају са назаренском пикторалном поетиком, присутном у ликовном програму бечкеречке капеле (TELESKO 2010: 11-38). 


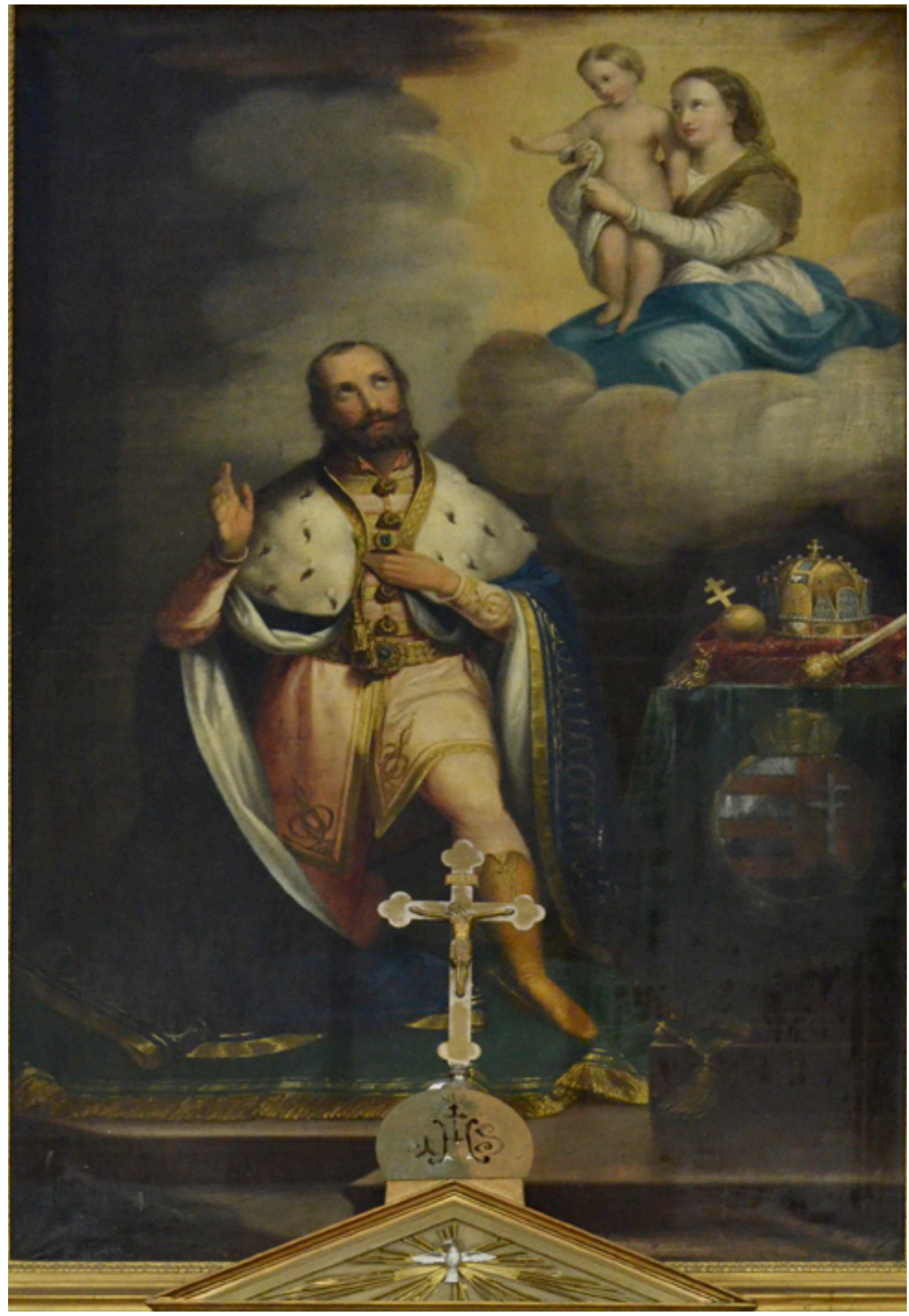

Сл. 2. Главни олтар са представом Светог Стефана, Јожеф Виплер, 1846. 
Пијаристичка гимназија у Бечкереку, заједно са капелом Светог Стефана Мађарског, целина је од великог значаја за локалну заједницу, како због образовног аспекта, тако и због свеопштег културно-политичког живота града. Њено оснивање подигло је углед Бечкерека који је, поред Сегедина и Темишвара, постао нови образовни центар Баната.

\section{Главни олтар}

Посвета капеле Светом Стефану, првом мађарском хришћанском владару, упућује на распрострањеност култа ове митске личности, неопходне у конституисању националне свести угарског народа (SMITH 1991: 163-164; KIRÁLY, PAPP 2018: 97). У складу са општим културно-политичким токовима XIX века, младе европске нације користиле су се визуелним представама као својеврсним механизмом пропагирања идеје о сопственој дуговечности. Позивајући се на античку и средњовековну прошлост, уобличену у фигуру епског праоца краља Иштвана и митског наратива о постању етничке групе, мађарска нација је фабриковала своју традицију (HoBSBAWM, RANGER 1992: 3-10, 263-288) у сврху потврде националног идентитета (SмIтн 1991: 163-164; МАКУљЕВИЋ 2006: 3-72, 255-318; KIRÁlY, РАрP 2018: 111-114).

Поручена у време подизања грађевине 1846 . године, централна олтарска слика Светог Стефана Мађарског најранији је сачувани пример сликарства пијаристичке гимназијске капеле (сл. 2). Први угарски хришћански монарх Свети Стефан (Szent István), на олтарској слици уметника Јожефа Виплера (József Wippler), представљен је у владарском орнату како предаје регалије Богородици, патронки угарских земаља (FERENC 2015: 18). У XIX веку европски народи се осврћу на често фабриковану, митолошку прошлост, те је култ Светог Стефана важна окосница угарске националне свести (SMITH 1991: 52; KIRÁLY, РAPP 2018: 111). Први угарски хришћански владар краљ Иштван (1000/1-1038) био је заслужан за покрштавање угарског народа, као и отварање бројних манастира и оснивање бискупија. Важна је и његова повезаност са Богородицом, којој Свети Стефан симболички предаје оруђе владавине и завештава јој угарску територију и народ, што је посебно наглашено на главној олтарској слици у гимназијској капели (МилАновић-Јовић 1976: 157). Идентитет угарске нације, саздан на легендама о митском оснивачу Арпаду и хришћанском владару Иштвану, неретко је наглашаван током XIX века на мултиетничким просторима попут Торонталске жупаније. Истицање дуговечности и правоверности етничке групе, отелотворене у представи Светог Стефана, представља механизме конституисања националног идентитета мађарског народа (SмIтH 1991: 171; VARGA 2016: 9, 13).

Посвета капеле и представа митског владара на главној олтарској слици показатељи су политичко-културне климе у Бечкереку средином XIX века.

О значају култа Светог Стефана у локалној заједници сведочи картуша са исписом изнад олтара (N. Becskereki Csizmadia, és Szijjártò egyesültérd.czéhnek R.katol.tagjai készitették. 1846). Архивска грађа упућује на донаторску делатност бечкеречког еснафа 
чизмаша, који је у години подизања капеле поручио израду олтарске слике са приказом патрона - Светог Стефана (МилАновић-Јовић 1976: 157). Поред исписа на картуши, на делатност наручиоца упућује и снажно обојена чизма Светог Стефана, јасно видљива у ставу молитве, у којем је патрон приказан. Приврженост култу митског владара, исказана кроз донаторску делатност локалног еснафа, упућује на значај истицања угарске националне припадности, али и препознавање значаја оснивања пијаристичке гимназије као важне образовне установе за заједницу Торонталске жупаније.

\section{Северни бочни олтар}

Северни део олтарског простора заузима бочни олтар са представом Јосефа Калазанца, оснивача пијаристичког монашког реда. Бочна олтарска слика поручена је 1847. године, а насликао ју је истакнути мађарски сликар Јожеф Пешки (József Peschky, 1795-

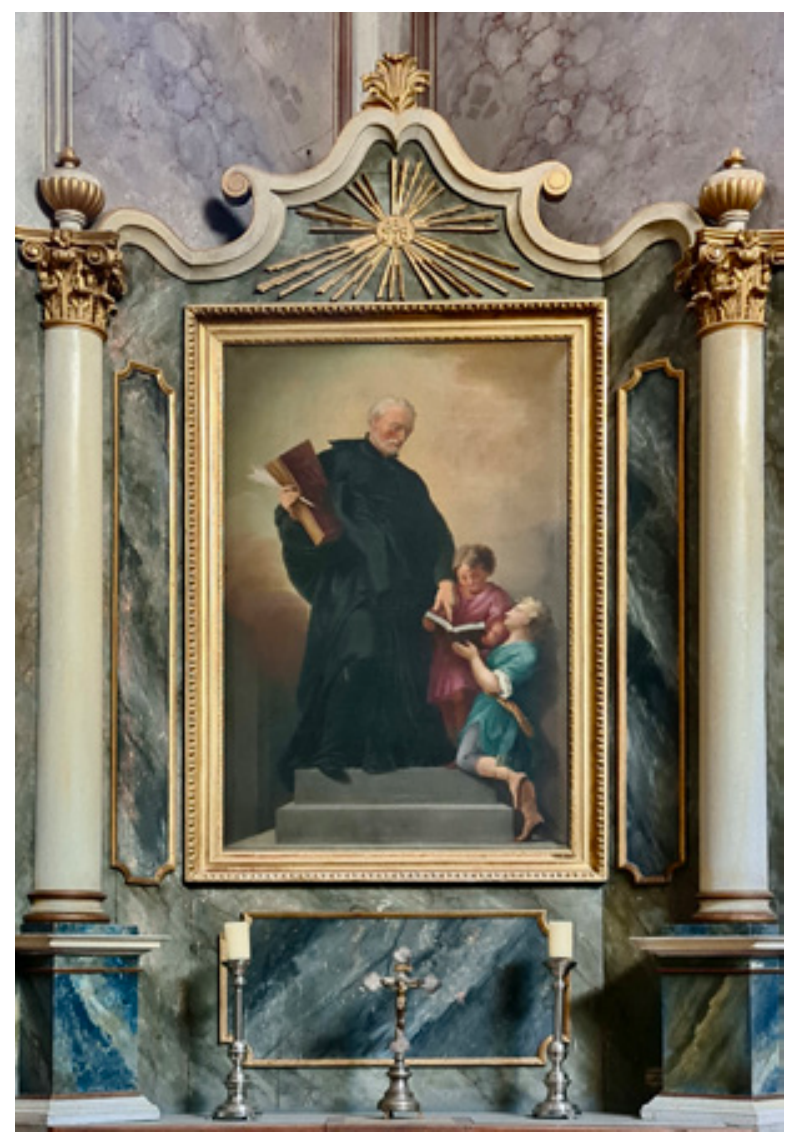

Сл. 3. Бочни олтар са представом Јосефа Калазанца, Јожеф Пешки, 1847.
1862). На њој је приказан поглавар пијаристичког монашког реда Јосеф Калазанц у гесту проповеди ђацима (сл. 3) (Милановић-Јовић 1976: 157).

Основан 1621. године, католички монашки ред пијариста био је превасходно посвећен образовању, а нарочито се залагао за милосрђе, чедност и послушност. Од XVII века делатност овог братства заступљена је на територији Хабзбуршке монархије, а водећу позицију на пољу црквеног образовања пијаристи преузимају по изгону језуита са хабзбуршких територија, у времену владавине цара Јосифа II (Joseph II, 1765-1790).

Пијаристички систем образовања премрежио је читаву Средњу Европу током XIX века, првенствено због свог либералног виђења школства, пружајући образовање најсиромашнијим слојевима друштва, као и припадницима других конфесија (ЂукАновић 2015: 136). Јосеф Калазанц, родоначелник бесплатног школства у католичком свету, претече данашњег државног 
(основног) образовања, у својој мисији наилазио је на отпор шпанске инквизиције. Оснивач пијаристичког реда канонизован је 1767. године, а папа Пије XII (Pius XII, 1939-1958) прогласио га је заштитником свих католичких јавних школа. Његова борба за племенит циљ у пијаристичкој догми слави се као уподобљавање Калазанца Христу, па су сцене парабола и страдања чест одабир у ликовном програму пијаристичких цркава (DOMÈNECH I MiRA 1998: 336-339).

На бочној олтарској слици у гимназијској капели Јожеф Пешки је представио Калазанца у канонској сцени обраћања деци, са уобичајеним атрибутима учености књигом и пером. Приказ Калазанца са ученицима уобичајен је део ликовног репертоара пијаристичких цркава и школа, са Црквом Марија Треу у Бечу (Piaristenkirche Maria Treu), као највећим упориштем пијариста у Средњој Европи, одакле је Јожеф Пешки могао преузети иконографски образац (DOMĖNECH I MIRA 1998: 327).

Као истакнути студент Бечке ликовне академије (Akademie der bildenden Künste Wien), коју је похађао од 1815. до 1818. године, Јожеф Пешки постаје етаблирани сликар, омиљен у родној Угарској. Претежно тражен као олтарски сликар, Пешки је често сликао приказе Светог Стефана и Светог Имреа, што иде у прилог тези о порасту националне свести на угарским територијама, инкорпориране у ликовни репертоар сакралних грађевина. Поруџбине за олтар Светог Јована Непомука у римокатоличкој цркви у месту Тортел (1835), као и у лутеранским црквама у местима Нађбержењ (1828) и Орошхаза (1838), потврдиле су статус Пешкија као мађарског сликара сакралне тематике XIX века (KIRÁLY, PAPP 2018: 111). Поруџбина за пијаристичку гимназијску капелу Светог Стефана сведочи о уметниковој популарности и распрострањености његовог рада, као и о потреби управе бечкеречке гимназије за ангажовањем цењеног мађарског сликара, у циљу подизања угледа ове образовне установе.

\section{Јужни бочни олтар}

Услед бурних историјских догађаја, који су се одиграли непосредно по оснивању пијаристичке гимназије, сликарски програм капеле Светог Стефана довршен је три деценије након подизања и осликавања главног и северног бочног олтара. Jужно оријентисани бочни олтар је 1879. године осликао Јозеф Лихтенегер (Josephus Lichtenegger) приказујући канонску представу Сикстинске Мадоне (Sistine Madonna) (1513), копије по Рафаелу (Raffaello Sanzio da Urbino, 1483-1520) (сл. 4) (Милановит-Јовић 1976: 157).

Култ Рафаела дубоко је укорењен у културу Средње Европе XIX века, а своју распрострањеност дугује назаренској пикторалној поетици, чији је утицај у том периоду диктирао норму сакралног ликовног израза. На култни статус Мадоне Сикстине и уврштавању нових вредносних категорија у то дело кроз векове упућују дела знаменитих културних првака попут Вазарија (Giorgio Vasari, 1511-1574), Винкелмана (Johann Joachim Winckelmann, 1717-1768), Енгра (Jan-Auguste-Dominique Ingres, 17801867) и Вакенродера (Wilhelm Wackenroder, 1773-1798) (БРАјОвић 2013: 109; БорОзАН 


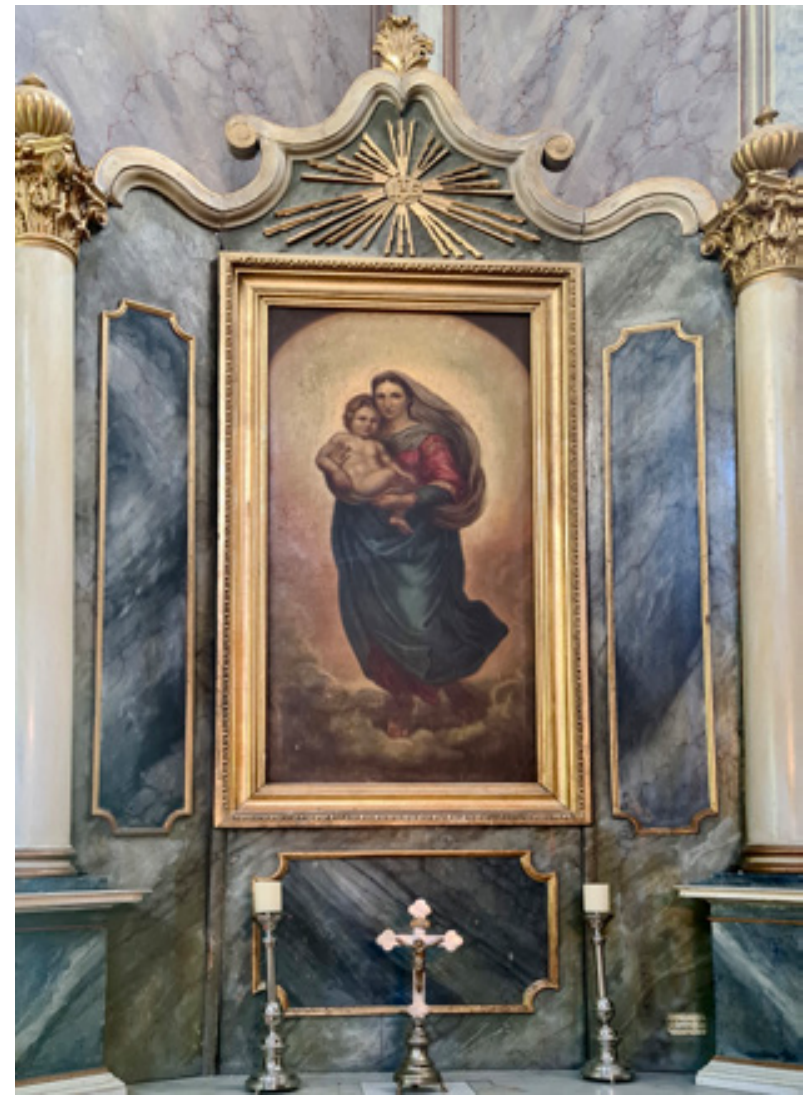

Сл. 4. Бочни олтар са представом Мадоне Сикстине, Јозеф Лихтенегер, 1879.
2017: 38). Поред богате традиције уздизања Рафаеловог лика и дела, иконичност ове представе и директна повезаност са немачким национом збила се у моменту када је краљ Август III (Augustus III / Frederick Augustus II) откупљује за Gemäldegalerie у Дрездену средином XVIII века. Тада ово дело, испрва у функцији олтарске слике, прераста у предмет уметничког обожавања, у који се учитава сва глорификација Рафаеловог генија - а по Винкелмановим речима, Сикстине као идеала класицизма. Уврштавањем у дрезденску збирку, Сикстинској Мадони се приписује и нови, политичко-национални карактер, те се дело германизује и уздиже на ниво култне слике немачког народа (БрАјовић 2013: 113). Рафаелова Сикстинска Мадона добија статус наднационалне, иконичне представе, која постаје отелотворење универзалног, класицистичког идеала о лепом и узвишеном, док истовремено представља окосницу општег процеса католич-

ке ревитализације у Европи (BÜtTNer, GOTTDANG 2013: 41-43).

Необичан пут Рафаелове слике индиректно је створио погодну климу за формирање назаренске пикторалне логике, односно Братства Светог Луке (Lukas brüder) - заједнице одметнутих студената Бечке ликовне академије, чији ће ликовни израз постати неприкосновени узор сакралног сликарства XIX века на тлу Средње Европе (GREWE 2009: 19; FACOS 2011: 106; БОРОЗАн 2018: 197). На челу са Францом Фором (Franz Pforr, 1788-1812) и Фридрихом Овербеком (Friedrich Overbeck, 1789-1869), започевши суживот у напуштеном манастиру Светог Исидора у Риму 1810. године, група младих сликара, огорчених наставним програмом Бечке академије, окушала се у богоугодном животу у циљу стварања „чисте” уметности. Отклон од класицистички центрираног силабуса Академије, на челу са Фридрихом Фигером (Heinrich Friedrich Füger, 1751-1818), навео је скупину младих уметника на радикалну промену ликовног израза. Жеља за променом начела и животног хабитуса условила је њихов бег у Рим, премештајући их 
у измаштано, златно доба средњовековне побожности и сликарског поступка (БрАЈОВИЋ 2013: 109; БОРОЗАН 2017: 16-17; 2018: 199).

Залажући се за субјективност, чистоту уметничког израза која деривира од Бога, назарени су инспирацију проналазили у стваралаштву старонемачких уметника и уметника ране ренесансе - Микеланђела (Michelangelo Buonarroti, 1475-1564), Фра Анђелика (Fra Angelico, 1395-1455), Дирера (Albrecht Dürer, 1471-1528) и надасве Рафаела (БРАјОвић 2013: 109; БОРОЗАН 2017: 15).

Манастир Светог Исидора постаје незаобилазна тачка у оквиру grand tour путовања, која су била уобичајена за академске уметнике тог времена. Од одметника академије, кроз неколико деценија, уметници назаренског кружока постајали су уважени професори академија Средње Европе, те се њихов утицај инфилтрира у европске академске токове друге половине XIX века. За продор назаренске пикторалне логике на тло јужне Угарске од великог значаја су аустријски назарени, на челу са Леополдом Купелвизером (Leopold Kupelwieser, 1796-1862), чија је јавна активност пете и шесте деценије XIX века изнедрила бројне уметнике, студенте Бечке академије (FeUCHTMÜLLER 1970: 152-153; БорОЗАН 2017: 13-18, 45).

Као недостижан идеал у назаренском космосу, Рафаелова Сикстина представљала је праслику, те стога - модел имитације. Питање копије Сикстине схватано је као апропријација недостижног уметничког оригинала, креативног и интерпретативног процеса. Ова доктрина преносила се на студенте средњоевропских академија, на челу са назаренским професорима, који су на тај начин ширили Рафаелов култ (БОРОЗАН 2018: 197).

Олтарска слика Сикстинске Мадоне Јозефа Лихтенегера у пијаристичкој капели Светог Стефана не схвата се као пука репродукција иконичног дела, већ сведочанство о распрострањености Рафаеловог култа.

Олтарски простор пијаристичке гимназијске капеле у својој целовитости уобличава вредности типичне средњоевропском културном миљеу XIX века, али истовремено указује и на преплитање националног, образовног и универзално естетског канона, стварајући јединствену ликовну и мисаону целину.

Олтар Светог Стефана Мађарског указује на заступљеност националног култа митског владара у локалној заједници Бечкерека, те сведочи о проналажењу националног идентитета у мултиетничкој средини Торонталске жупаније.

Представа Јосефа Калазанца као врховног учитеља могла је функционисати као својеврсни модел уподобљавања професора бечкеречке гимназије, односно симбол пијаристичких постулата, отелотворен у лику Светог Калазанца, те сведочи о утицају које је братство имало на образовни систем јужне Угарске (DOMĒNECH I MIRA 1998: 338).

Иконична представа Мадоне Сикстине у својој присутности сублимира постулате позноназаренске пикторалне логике, односно ванвременског Рафаеловог култа, чији је утицај евидентан и на обронку угарских територија. 


\section{Зидно сликарство}

Зидно сликарство из 1879. године дело је бечкеречког сликара Јозефа Гојгнера (Josef Goigner, 1837-1887). Одабир сцена, ликовних предложака, као и клима у којој се Гојгнер развијао као уметник, упућују на уплив идеја позноназаренске пикторалне логике, које се директно транспонују на сликарски репертоар пијаристичке капеле.

Родом из места Гоигн код Кицбила у области Тирол, сликар Јозеф Гојгнер прешао је дугачак пут да би постао градски бечкеречки сликар. Младост и рано образовање овог уметника нису расветљени, али на основу архивске грађе закључује се да је извесно време боравио у Минхену и Бечу, похађајући курсеве на академијама (ШијАковић 1987: 106-108). Поуздан је податак да се образовао у пештанском атељеу Морица Лемана (Moritz Lehmann, 1819-1877), еминентног сликара декоратера и сценографа, чије су се сценографије, поред бечких позоришта где је највише радио, налазиле и у Вроцлаву, Риги, Берлину, Лајпцигу и Будимпешти. Као тражени сценограф, Леман је често путовао и извесно је да је младог Гојгнера упознао са простором јужне Угарске (ÖSTERREICHISCHES BIOGRAPHISCHES LEXIKON 1972; ШИJAKOBИЋ 1987: 115; FERENC 2015: 30-31).

О датовању сликаревог доласка у Банат сведочи оглас из Великобечкеречкої неgељника (Gross-Becskereker Wochenblatt, 1871), у ком Гојгнер слави десетогодишњицу живота и рада у Бечкереку отварањем новог атељеа, што наводи на податак да је око 1861. године постао бечкеречки становник. Оформивши се као важна градска личност, Јозеф Гојгнер је уживао велики углед, о чему сведоче бројне поруџбине зидног сликарства, као и позоришне декорације, уља на платну и фотографије. Гојгнер је као студент Морица Лемана овладао сликаном декорацијом и веома је успешно уобличавао црквене објекте на територији Баната. О обиму рада и потражњи говори отварање Гојгнерове шегртске радионице 1874. године. Осликавао је римокатоличке и православне цркве од којих је, поред програма зидног сликарства пијаристичке капеле, важно истаћи радове у црквама у Сечњу, Равном Тополовцу, римокатоличкој и православној румунској цркви у Ечки, православној цркви у Карлову (1872) и римокатоличкој катедрали у Бечкереку (1884/5) (ШијАкОВић 1987: 108-111).

Поред изражене орнаментике и богатог илузионистичког, еклектичног украса, несумњивог наслеђа Леманове школе, Гојгнер је неретко проналазио упориште у сликарству назарена.

За популаризацију назаренске религиозне слике заслужни су нови медији, а посебно илустроване Библије, које су флуктуирале дотадашње поимање представљања библијског наратива. Међу најпопуларнијим издвајају се издања Јулијуса Шнора фон Каролсфелда (Julius Schnorr von Carolsfeld, 1794-1872) и Гистава Дореа (Paul Gustave Dore, 1832-1883), чијим је посредством назаренска религиозна слика премрежила Европу (Grewe 2009: 15-16, 206; KAENEL 2014: 181; БОРОЗАН 2017: 45).

Дореова илустрована Библија садејствује са актуелним археолошким открићима

друге половине XIX века која су утемељена на примени нових сазнања у сликарству, аутентичним приказом античких и библијских костима, архитектуре и предела. 
Постулати историјског сликарства, које почива на истинитости, односно верном приказу догађаја из прошлости, сада се транспонују и у домен религијског сликарства (Тимотијевић 2002: 369). У конституисању веродостојног приказа библијске историје, према постулатима актуелне идеалистичке естетике, била је неопходна и врста артифицираности, умешност ублажавања реалности у приказу библијских наратива (GREWE 2009: 22, 207; БоРОзАН 2017: 16). Ова врста тежње ка историјској егзактности, у извесној мери заступљена је у илустрованој Библији Гистава Дореа. За разлику од својих савременика, Доре није путовао на Блиски исток у тежњи за веродостојним приказом прошлости, већ се махом користио грађом којом је располагао у Француској - музејским експонатима, графикама и бројним научним и пустоловским публикацијама. Створивши баланс између измаштаног и егзактног, задовољавајући естетске и археолошке захтеве, Дореови прикази библијске историје постали су доминантни ликовни предлошци сликара Европе (GREWE 2009: 207209; KAENel 2014: 22; SCHAEFER 2014: 86, 94-98).

Користећи се предлошцима Дореове илустроване Библије, Гојгнер је на седам сцена, у пијаристичкој капели Светог Стефана, представио начела која су саобразна тежњама управе бечкеречке гимназије, под окриљем пијаристичког монашког реда. Са фокусом на параболе и сцене мучеништва, циљ осликавања овог сакралног простора био је пропагандно-едукативни. Слике на своду капеле уклопљене су у декоративне, барокне картуше, док су оне на зидовима смештене у сликане, позлаћене рамове и запремају стварна архитектонска рашчлањења цркве. У потпуности преузимајући Дореову иконографску схему, Гојгнер је представио седам сцена из библиј-

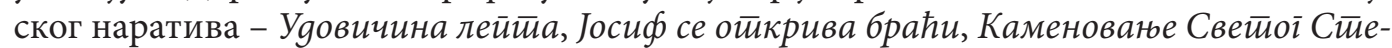
бана, Васкрс Јаирове кћери, Пусиичйе деиу к мени, Христиос и Самарјанка и Молитива

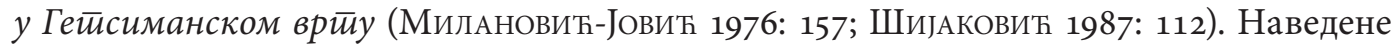
сцене представљене су у типично назаренском стилу, који дефинише изражена пасивност фигура, умртвљеност лика и одсуство геста, у циљу пружања предности идеје над акцијом (БорОЗАН 2017: 31-32). Гојгнеров колорит дефинише расветљена, пастелна палета, блиска назаренском сликарству, веома популарна у времену осликавања пијаристичке капеле. Назаренско поимање библијске историје, па и одабир приказа библијске личности, условљено је симболичком поруком коју је потребно да представа еманира. Схватане као својеврсне визуелне метафоре, сцене су могле бити тумачене из више ракурса (BÜtTNER, GOTTDANG 2013: 42; БоРОзАн 2017: 19).

Сцена Уgовичине лейие, која се налази на северном зиду западног травеја капеле Светог Стефана, може се разумети као симболички приказ једног од главних постулата пијаристичког реда (сл. 5). Прича је забележена у новозаветном Јеванђељу по Марку (12: 41-44) и илуструје наратив о сиромашној удовици која је приложила кованицу у кутију за прилоге, након Христове беседе у јерусалимском храму. Истицањем ове представе, фокус се ставља на значај проповеди и племениту делатност пијаристичког братства. Такође, архивска грађа упућује на потешкоће у прикупљању средстава за изградњу гимназије, те на велику финансијску помоћ грађана 


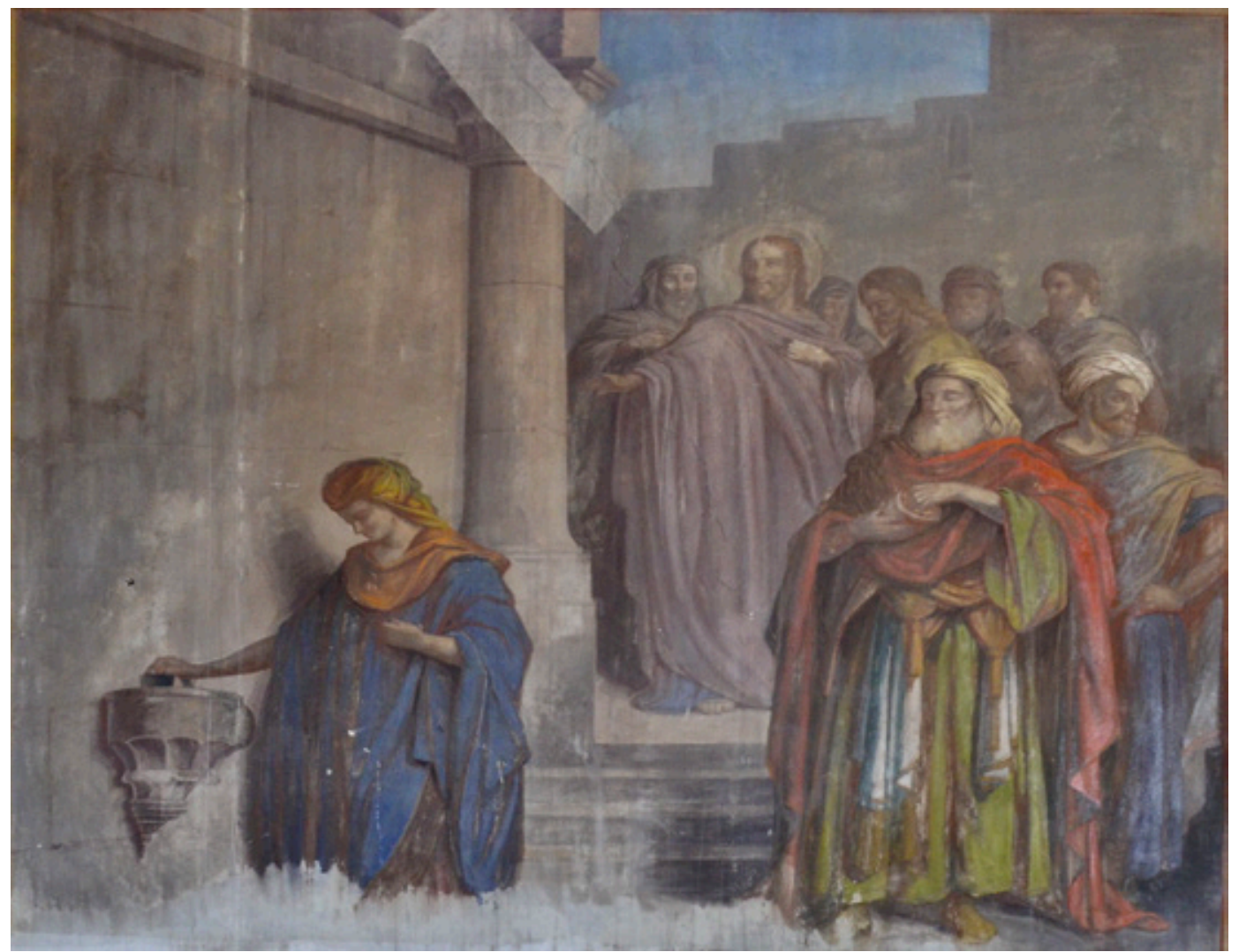

Сл. 5. Уgовичина леййа, Јозеф Гојгнер, 1879.

Бечкерека. Наратив о несебичном приложништву сиромашне удовице могао је комуницирати истовремено као дидактичка порука ученицима гимназије, али и као знак захвалности приложницима који су омогућили оснивање те установе (FERENC 2015: 19).

Постављена у овалној картуши на своду западног травеја, представљена је старозаветна сцена Јосиф се ойкрива браћи, из Прве књиге Мојсијеве (45: 1-4) (сл. 6). Јосифов циклус говори о старозаветном пророку којег су браћа продала у робље, а који је Божјом промисли постао најмоћнији дворанин египатског фараона. Одабир овог библијског наратива, који говори о праштању и спасењу, кореспондира са животом оснивача пијаристичког братства - Јосефом Калазанцом. Наилазећи на препреке од стране црквене управе, оних који су се противили пропагирању „слободног” школства, односно омогућавању бесплатног образовања припадницима других конфесија, као и сукобом са инквизицијом због приклањања Галилејевим научним открићима, Калазанц је истрајао у својој мисији због које је, након смрти, проглашен за свеца (DOMĖNECH I MiRA 1998: 328-329; GREWE 2009: 50-53; FACOS 2011: 107). 


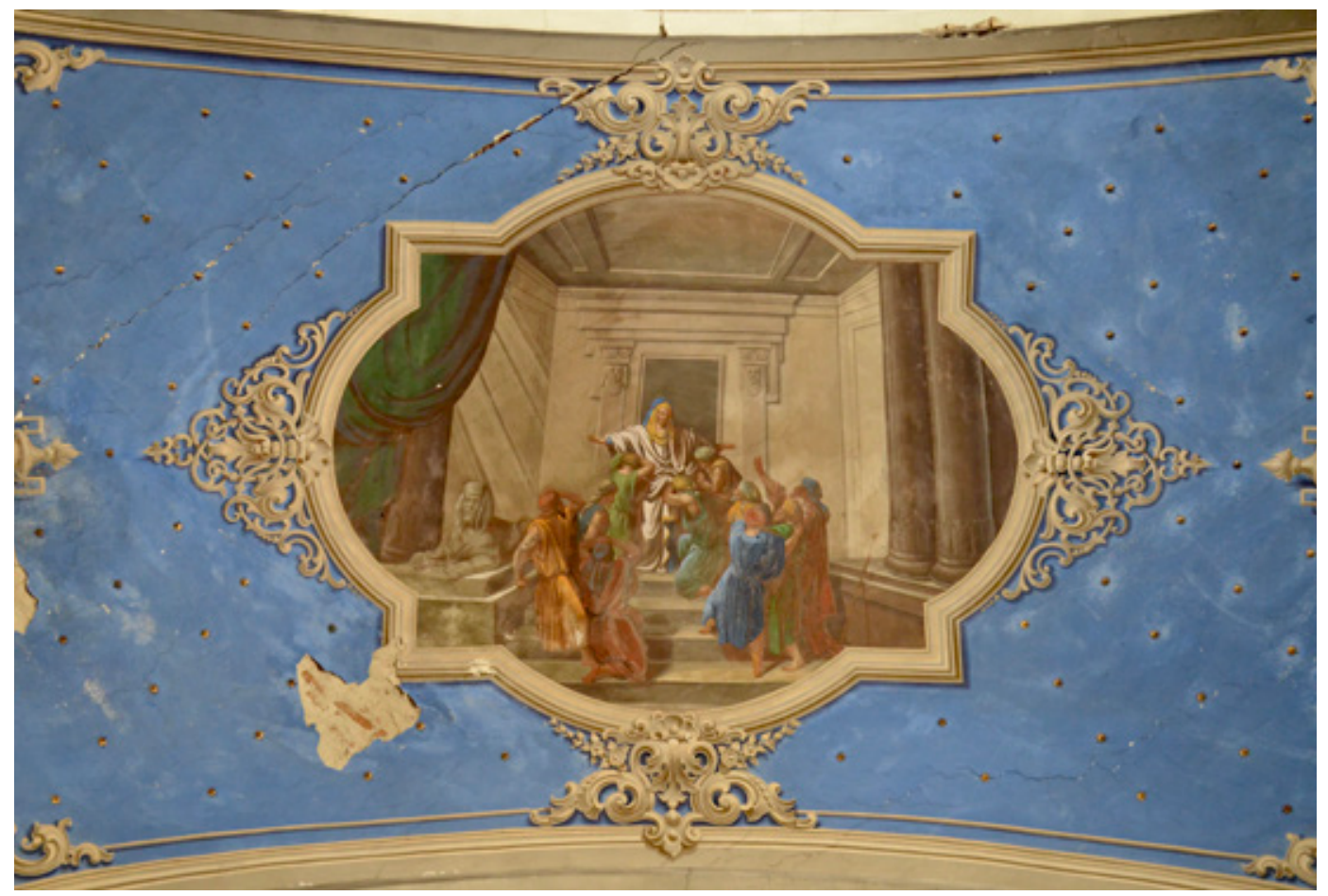

Сл. 6. Јосиф се ойкрива браћи, Јозеф Гојгнер, 1879.

Приказ пророка Јосифа, који прашта браћи за недела и истовремено им се открива као најутицајнији човек Египта, представља старозаветну префигурацију Христа. Поређење биографских догађаја важних црквених личности са животом Христа и других библијских ликова, уобичајена је пракса у хришћанском свету, те је дискурс о преброђеним животним неприликама зарад вишег циља вођеног Божјом промисли, у каквом се нашао пијаристички првак, уврштен у ликовни репертоар ове капеле.

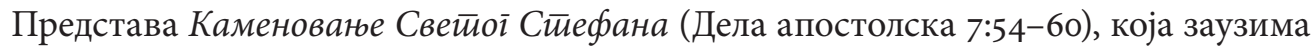
простор јужног зида западног травеја, умногоме се може довести у везу са посветом цркве (сл. 7). Као први угарски хришћански монарх, Свети Стефан Мађарски, рођен као паганин Вајк (Vajk), по примању вере, христијанизује своје име и преузима идентитет првог хришћанског мартира - Светог Стефана (5-33/6). То сведочи о политизацији хришћанске историје, која ће достићи свој зенит у времену конституисања нације и осећања националне и религијске припадности у XIX веку. Сагледано у пијаристичком кључу, милостивост ранохришћанског свеца, као и његова помоћ сиромашним члановима заједнице, кореспондира са начелима овог монашког реда (VARGA 2016: 27; KirÁLY, PAPP 2018: 111). 


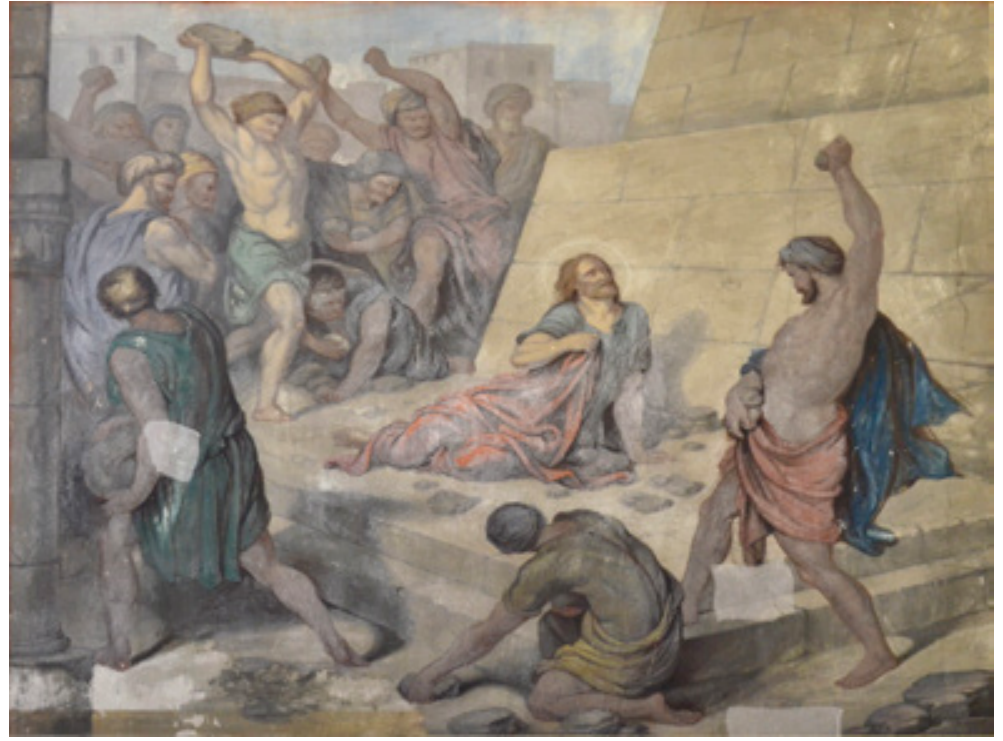

Сл. 7. Каменоване Свейой Сйефана, Јозеф Гојгнер, 1879.

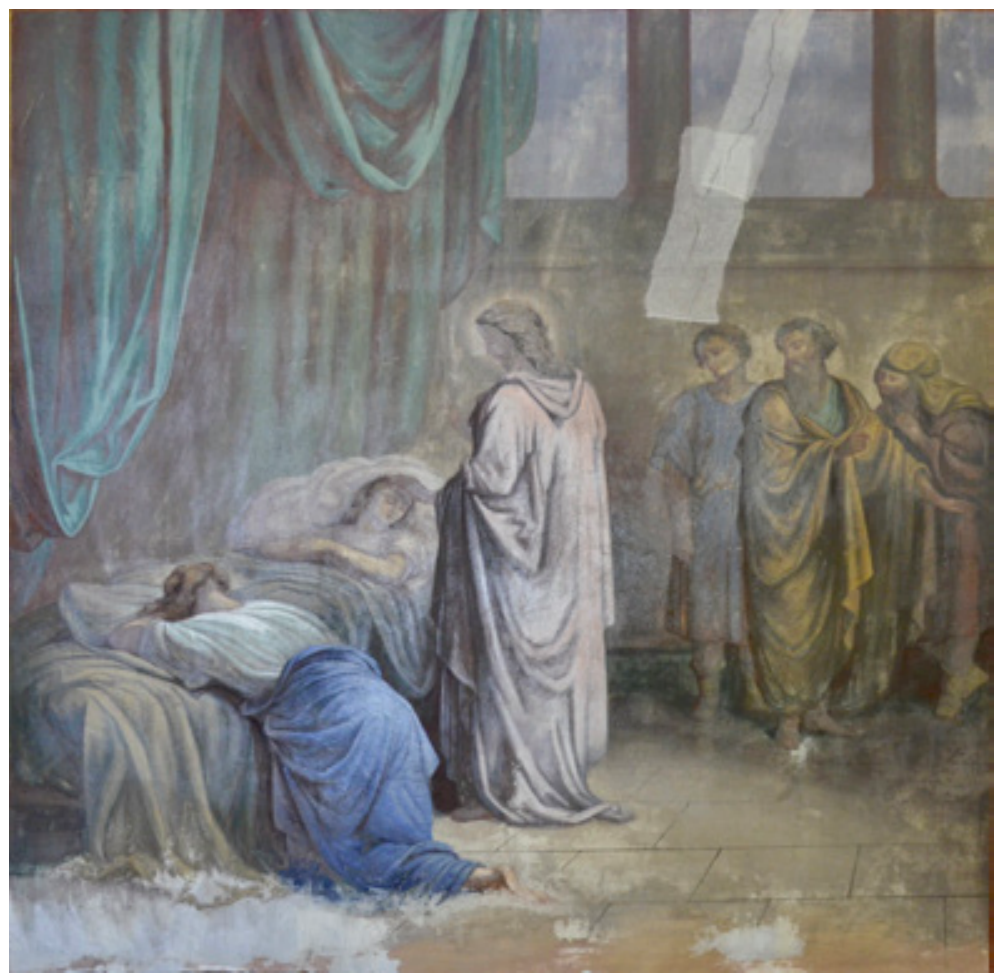

Сл. 8. Васкрс Јаирове кћери, Јозеф Гојгнер, 1879. 
Северни зид источног травеја пијаристичке гимназијске капеле заузима представа Васкрса Јаирове кћери (сл. 8). Наратив о чудесном васкрсењу из мртвих, описан у новозаветним јеванђељима (Марко 5: 21-43, Матеј 9: 18-26, Лука 8: 40-56), поново се може надовезати на епизоду из живота пијаристичког оснивача. По завршетку свог образовања 1582. године, Јосеф Калазанц је тежио животу посвећеном Богу, од чега га је одговарала породица. Разболевши се исте године и увидевши по опоравку да је то била Божја интервенција, Калазанц постаје свештеник у бискупији Ургел, у Каталонији. Овај догађај се у пијаристичком братству схвата као пресудан за стварање монашког реда. Његова одлука да посвети живот Богу резултирала је у проналажењу животног позива, образовању сиромашних, и изнедрила најуспешнији облик црквеног образовања познатог католичком свету (DOMĖNECH I MIRA 1998: 337). Биографски догађај из живота пијаристичког првака тако се може довести у везу са библијском причом чуда Христовог, васкрса Јаирове кћери, као врсте трансформације неживог у живо тело, односно смрти профаног и рођења световног Калазанца (GREWE 2009: 210).

Свод источног травеја капеле заузима представа Пустиийе gеиу к мени, која се помиње у Јеванђељу по Луки (18: 15-17) (сл. 9). Христос својим ученицима говори да су они који улазе у царство небеско налик деци, невини и непоколебане вере. Овај

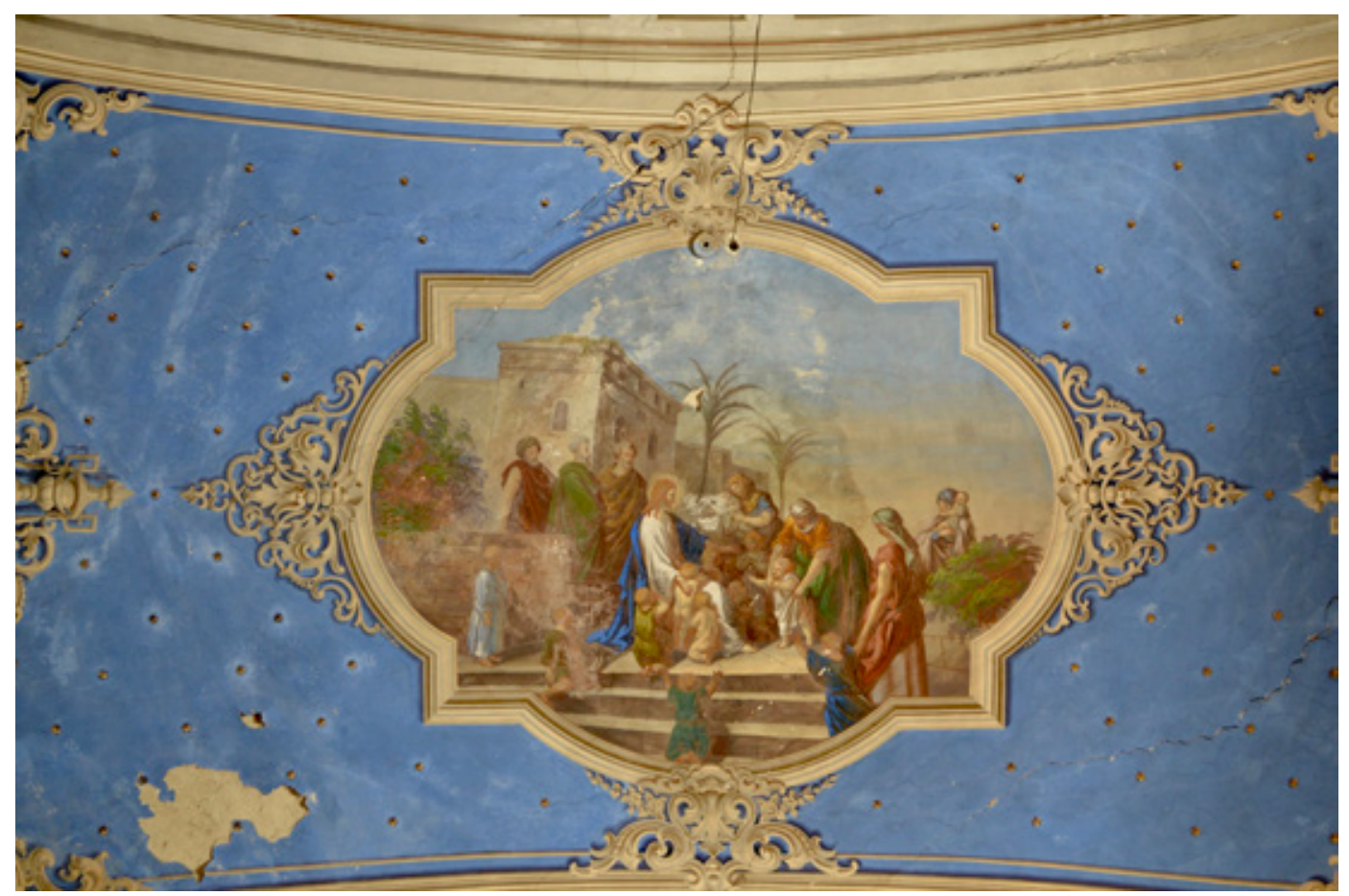

Сл. 9. Пусиииие gеиу к мени, Јозеф Гојгнер, 1879. 


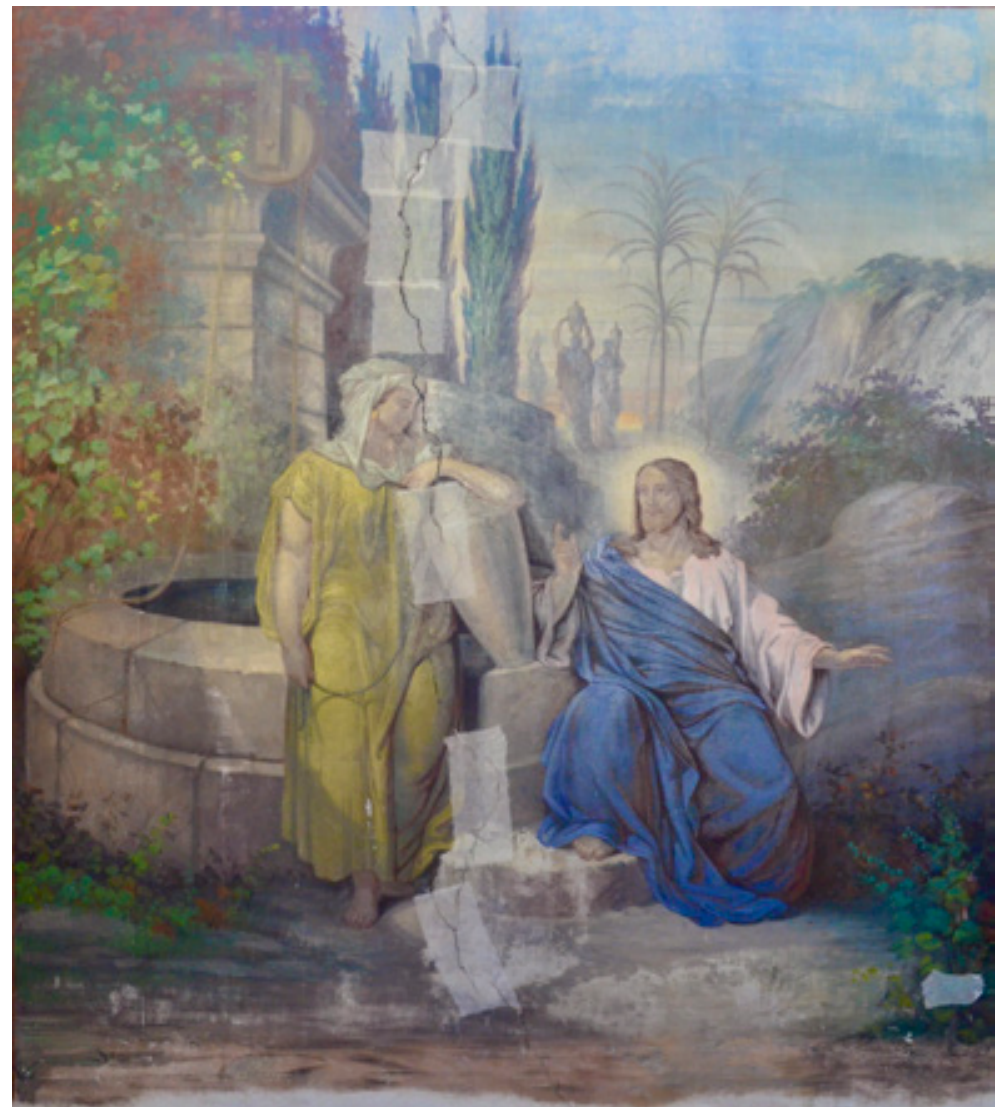

Сл. 1о. Хрисӣ и Самарјанка, Јозеф Гојгнер, 1879.

библијски наратив поставља тежиште на децу као настављаче хришћанске вере и неопходности упознавања са хришћанским постулатима у раном добу. Дидактичка порука ове библијске епизоде кореспондира са образовном мисијом пијаристичког братства, као и са сакралним простором гимназијске капеле, у којој је смештена (ТимоТИJЕВИЋ 2002: 369; GREWE 2009: 216). Врло честа сцена у назаренском ликовном програму, представа Пустиите gеиу к мени симболично сједињује образовни и религиозни карактер капеле, кроз уподобљавање приказа деце са ученицима пијаристичке гимназије, као и професора са пијаристичким поглаваром, те уједно са Христовом јавном делатности.

Представа Хрисӣа и Самарјанке, чији је извор Јеванђеље по Јовану (4: 6-42), приказана је на јужном зиду источног травеја пијаристичке гимназијске капеле. Милосрђе као главна тема библијске приче о разговору Христа и самарјанске жене на студенцу илуструје једно од главних начела пијаристичког монашког реда (сл. 10). 


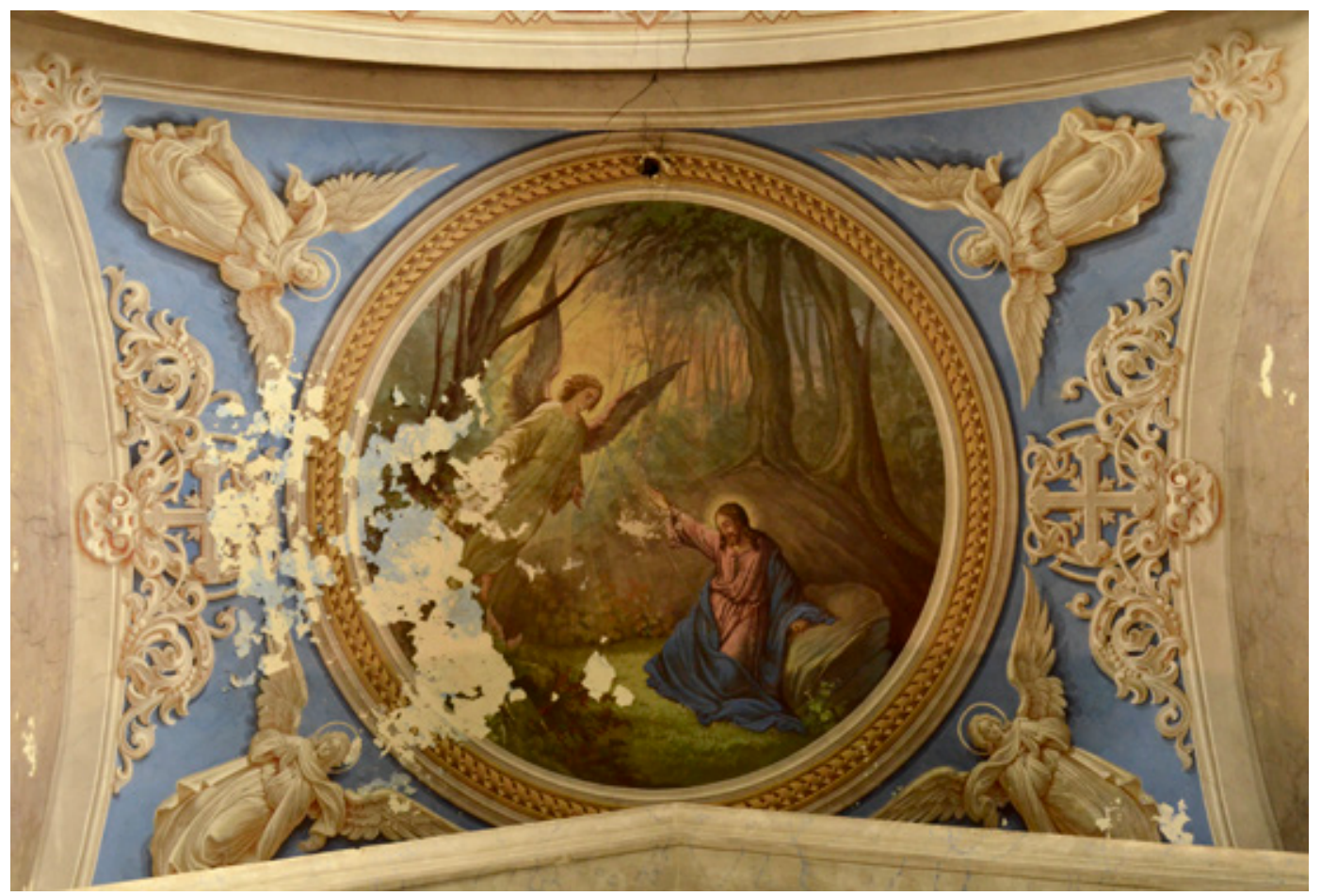

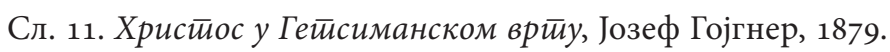

Метафора воде и божанског знања која се помиње у овом библијском наративу такође се може сагледати у контексту образовања под окриљем монашког реда, односно вере као непресушног извора мудрости и бољитка.

Изнад главне олтарске слике са представом Светог Стефана Мађарског у своду централног дела олтарског простора насликана је представа Молийве у Гейсиманском врйу (сл. 11). На основу приказа фигуре анђела закључује се да је цитат преузет из Јеванђеља по Луки (22: 39-46), у ком се, у поређењу са другим јеванђељима, једино помиње његово присуство.

Христова молитва Богу је прича о неизбежној судбини хришћанског спаситеља - страдању Божјег сина. Овај тренутак библијског наратива расветљава људски аспект Христа, те се он открива као човек који се колеба и стрепи. Сложена структура овог наратива представља парадигматску слику назаренског првака Фридриха Овербека, кроз чију се призму може сажети идеја назаренског пикторалног наслеђа (GREWE 2009: 15; БОРОЗАН 2017: 31).

Овербек је одабиру теме приступао из позиције теолога, проучавајући Библију и другу теолошку грађу, о чему сведочи и његова писана заоставштина. Темељно приступајући религиозним списима, идеолошки опредељен, Овербек је имао циљ 
да теолошки делује на посматрача путем слике. Захваљујући распрострањености назаренског сликарства, ова сцена постаје чест мотив у ликовном програму сакралних простора, па је присутна и у стваралаштву зидног сликарства Јозефа Гојгнера (БОРОЗАН 2017: 25-28).

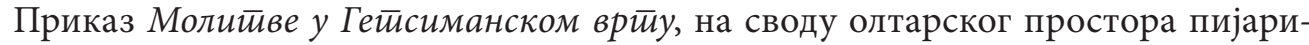
стичке капеле, комуницира са позноназаренским наслеђем, које је премрежило територије Средње Европе друге половине XIX века, али и жртвеним карактером самог сакралног простора у којем је смештена. Христос као спаситељ, у тренутку помирења са неминовним страдањем, у приказу узвишене верске емоције блиске назаренском учењу, постављен је на највишу тачку олтара - најсакралнијег простора пијаристичке гимназијске капеле.

Монументално фреско-сликарство у пијаристичкој капели одјек је ширих тенденција европске уметности XIX века. Упућујући на значај монументалног историјског сликарства у сврху подстицања националног осећања, Петар Корнелијус је 1814. године саставио писмо које ће консеквентно допринети ревитализацији фреско-сликарства на тлу Средње Европе у XIX веку. Корнелијус је писмом позвао владаре и државне институције да се заузму за монументалну уметност, која би поседовала наглашен отаџбински дух и тако имала обавезујуће дејство на народ, те ојачала осећај националне повезаности. Већ 1816. године, Корнелијусова иницијатива је уродила плодом, па назарени добијају налог од пруског генералног конзула у Риму Јакоба Саломон Бартолдија (Jakob Salomon Bartholdy, 1779-1825), за монументалну фреско-декорацију. Успех ових фресака, које су илустровале циклус о Јосифу, превазишао је очекивања и 1818. године краљ Лудвиг (Ludwig I, 1786-1868) даје налог Корнелијусу да декорише Глиптотеку у Минхену. Овај захтев се слагао са Корнелијусовом визијом монументалне јавне уметности, библијског наратива који није инклузиван, већ директно утиче на живот и доприноси балансу духа времена и националног карактера (LOCHER 2005: 52-57; GREWE 2009: 33, 55; FACOS 2011: 106; БОРОЗАН 2017: 28, 37-41; KirÁly, PAPP 2018: 631, 639).

Поновно оживљавање монументалних композиција у стилу италијанске ренесансе, као нове тенденције назаренског сликарства, имало је удела и на територијама јужне Угарске. Средином века црква постаје ангажована национална институција, те се јавља потреба за проширивањем тематског репертоара, па сакрална здања постају врста верско-националних споменика. Тежња за свеобухватним изразом изнедрила је ликовне програме, који обједињују општехришћанске са национално-црквеном и политичком историјом. У овом комплексном механизму национализације вере и сакрализације нације, репертоар зидног сликарства Јозефа Гојгнера у пијаристичкој капели сведочанство је времена и њеног сложеног културно-политичког карактера (ТИмОтИјЕвИЋ 2002: 369; БОРОЗАН 2017: 14; KiRÁlY, PAPP 2018: 108-110). 


\section{Закључак}

Пијаристичка гимназија Светог Стефана у својој целини сублимира идеје специфичне средњоевропском културном миљеу у датом временском оквиру. Посвета грађевине светом угарском владару упућује на сложени механизам конституисања националног идентитета и осећаја припадности мађарског народа XIX века. Истичући своју дуговечност изграђену на хришћанским вредностима, Мађари успостављају примат над територијом Торонталске жупаније, што сведочи о напетом односу на овом мултиетничком простору, који ће непосредно након оснивања гимназије прерасти у отворени сукоб. Истицање митске прошлости опште је место у европској политичкој клими XIX века, а о утицају тих тенденција на локалну заједницу сведочи донаторски гест бечкеречког еснафа за осликавање представе Светог Стефана, на главном олтару гимназијске капеле. Пропагирањем култа Светог Стефана на територијама где је присутан мађарски национ, наратив о митској угарској прошлости је претрајавао, те је и осећај припадности етничкој групи јачао.

Истовремено капела пијаристичке гимназије је служила ученицима и професорима бечкеречке гимназије, те је ликовни програм имао првенствено дидактичку функцију. Ученици су путем визуелних представа усвајали вредности пијаристичког братства, а такав вид визуелног приповедања био је саобразан са назаренском доктрином приповедања путем слика. Назаренско поимање цркве као космолошког центра света кореспондира са зидним сликарством капеле, где монументалне сцене библијских наратива функционишу као Библија у причама, стварајући нераскидиву нит идеја илустрованих Библија, назаренске доктрине и монументалног фреско-сликарства. У случају ликовног програма гимназијске капеле, репертоар је на карактеристичан начин устројен и може се тумачити у пијаристичком и назаренском смислу, што га чини утолико комплексним и јединственим примером сакралног сликарства на простору јужне Угарске. У својој целини, сликарство пијаристичке капеле одговара визуелизацији преноса општих назаренских ликовних порука у локални контекст Бечкерека.

\section{ЛИТЕРАТУРА}

БАКИЋ, Светлана. „Рестаураторски радови на три цркве у Зрењанину.” Грађа за ирроучавағе сйоменика кулииуре Војвоgине (ВАКІс́, Svetlana. "Restoration works for three churches in Zrenjanin." Građa za proučavanje spomenika kulture Vojvodine) XXI (2004): 32-33.

БАКИЋ, Светлана. „Архитектонско и урбанистичко наслеђе Зрењанина.” Грађа за йроучаване сиоменика кулииуре Војвоgине (ВАкіс́, Svetlana. "Architectual and urbanistic heritage of Zrenjanin." Građa za proučavanje spomenika kulture Vojvodine) XXII-XXIII (2008): 47-49.

BÜTTNER, Frank, Andrea Gottdang. Einführung in die Ikonographie: Wege zur Deutung von Bildinhalten. München: C. H. Beck Studium, 2013. 
БорОзАН, Игор. „Култ Рафаела и назаренско сликарство: Боі̄ороgии а са Христиом Аксентија Мародића на ковиљском иконостасу." Саойшӣенье (BOROZAN, Igor. "Cult of Raphael and Nazarene painting: Madonna and Christ by Aksentije Marodić on iconostasis of Kovilj." Saopštenje) L (2018): 197-212.

БорОзАН, Игор. „Између историје и вере: Јохан Фридрих Овербек и уметност немачких назарена." У: БОРОЗАН, Игор (ур.). Димийрије Аврамовић. Уметиник евройских оквира и срйскоі конйекстиа. Нови Сад: Галерија Матице српске (BOROZAN, Igor. "Between History and Faith: Johann Friedrich Overbeck and the Art of the German Nazarenes." In: BorOZAN, Igor (ed.). Dimitrije Avramović. Artist of the European framework and Serbian context. Novi Sad: Galerija Matice srpske), 2017, 13-47.

БРАјОвИЋ, Саша. „Рафаел у ренесанси и европској нововековној култури.” У: ПАЛКОвљЕВИћ, Тијана, Илијас Тасијас (ур.). Humanism and Renaissance in Central Apennines. Parallell. Нови Сад: Галерија Матице српске, SIL Appennino Centrale (BRAJOviĆ, Saša. "Raffaello nella cultura europea dell'epoca moderna / Raphael in modern European culture." In: PALKOVlJEVIĆ, Tijana, Ilias Tasias (eds.). Humanism and Renaissance in Central Apennines. Parallels / Umanesimo e Rinascimento nelll'Appennino Centrale, Parallelli. Novi Sad: Galerija Matice srpske, SIL Appennino Centrale), 2013, 96-117.

VARGA, Bálint. The Monumental Nation, Magyar Nationalism And Symbolic Politics In Fin-De-Siècle Hungary. New York: Berghahn Books, 2016.

Grewe, Cordula. Painting the Sacred in the Age of Romanticism. Burlinghton: Ashgate Publishing, 2009. DOMĖNECH I MIRA, Josep. "Joseph Calasanz (1557-1648)." PROSPECTS: the quarterly review of comparative education vol. XXVII, no. 2 (June 1998): 327-339.

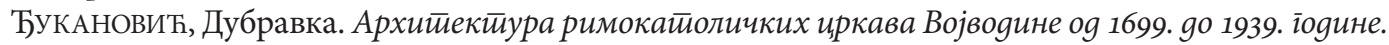
Нови Сад: Покрајински завод за заштиту споменика културе (ĐUKANOVIĆ, Dubravka. Architecture of Roman Catholic Churches in Vojvodina from 1699 to 1939. Novi Sad: Pokrajinski zavod za zaštitu spomenika kulture), 2015.

KAENEL, Phillippe (ed.). Gustave Dore (1832-1883): Master of Imagination. Paris: Musée d'Orsay Flammarion, 2014.

KIRÁlY, Erzsébet, Papp Júlia. A magyar müvészet a 19. században KÉPZÖMŰVÉSZET. Budapest: Mta Btk - Osiris, 2018.

Locher, Hubert. Deutsche Malerei im 19. Jahrhundert. Paderborn: Primus Verlag, 2005.

МАКУљЕВИЋ, Ненад. Умейности и национална ияеја у ХІХ веку - систием евройске и срйске визуелне кулииуре у служби нације. Београд: Завод за уџбенике (MAKULJEVIĆ, Nenad. Art and National Idea in the $19^{\text {th }}$ Century - System of Europian and Serbian Visual Culture in service of the Nation. Beograd: Zavod za udžbenike), 2006.

МикАвицА, Дејан, Ненад Лемајић и др. Срби у Хабзбуршкој монархији 1526-1918. 1. Нови Сад: Прометеј (MikaVICA, Dejan, Nenad Lemajić etc. Serbs in Habsburg Monarchy 1526-1918. 1. Novi Sad: Prometej), 2016.

МилАновић-Јовић, Оливера. „Из сликарства и примењене уметности у Банату.” Грађа за ироочаване сиоменика кулитуре Војвоgине (Milanović-Jović, Olivera. "Of the Painting and Applied Arts in Banat.” Građa za proučavanje spomenika kulture Vojvodine) VI-VII (1976): 157-158.

MileKer, Feliks. Istorija varoši Veliki Bečkerek 1333-1918. Zrenjanin-Beograd: Istorijski arhiv - IP Beograd, 2011. 
ÖSTERREICHISCHES BIOGRAPHISCHES LEXIKON 1815-1950 (Vol. 5). Wien, 1972, 52-57.

Поповић, Милош. „У Великом Бечкереку, 10. фебруара.” Србске новине (Popović, Miloš. “In Nagybecskerek, February 10 ${ }^{\text {th }}$." Srbske novine) 15. 2. 1849: 2.

SMITH, Anthony D. National Identity. London: Penguin books, 1991.

СтАнолЛовић, Александар. Петировірраg. Петровград: Штампарија Сава Толицки Мартинов (STANOJlović, Aleksandar. Petrovgrad. Petrovgrad: Štamparija Sava Tolicki Martinov), 1938. TELESKO, Werner. Das 19 Jahrhundert. Eine Epoche und ihre Medien. Wien: Bohlau Verlag Gmbh $\mathrm{U}$ Co Kg, 2010.

Тимотијевић, Мирослав. Релиіиозно сликарстиво као исииоријска истиина. Београд: Републички завод за заштиту споменика културе (TIмOTIJEVIĆ, Miroslav. Religious painting as a Historical truth. Beograd: Republički zavod za zaštitu spomenika kulture), 2002, 362-388.

FACOS, Michelle. An introduction to nineteenth century art: artists and the challenge of modernity. Abingdon: Routledge, 2011.

FERENC, Németh. A Nagybecskereki Piarista Gimnázium Története 1846-1920.

$<$ https://mtt.org.rs/wp-content/uploads/Nemeth-Ferenc-Piaristak-2015.pdf> 27. 1. 2021.

FEUCHTMÜLleR, Rupert. Leopold Kupelwieser und die Kunst der österreichischen Spätromantik. Wien: Österreichischer Bundesverlag für Unterricht, Wissenschaft und Kunst, 1970.

HobsBawm, Eric, Ranger Terence. The Invention of Tradition. Cambridge: Cambridge University Press, 1992.

SCHAEFER, Sarah C. "From the Smallest Fragment": The Archaeology of the Doré Bible." Nineteenth-Century Art Worldwide 13 no. 1 (2014): 78-104.

ШијАковић, Милева. „Великобечкеречки сликар Јозеф Гоигнер.” Улазнии (ŠIJAкоVIĆ, Mileva. "Jozef Goigner Nagybecskerek painter." Ulaznica) 110 (1987): 106-115.

Vanja V. Stojković

\section{THE PIARIST CHAPEL OF SAINT STEPHEN IN ZRENJANIN - HISTORY AND PAINTING}

\section{Summary}

The Piarist Gymnasium in Zrenjanin (former Becskerek) was founded in 1846 and it soon became a very important educational institution of Torontal county, a region of South Hungary.

Situated in a multiethnic region of Torontal county, the Piarist Gymnasium provided a proper education for pupils of different religious and national backgrounds. The Piarist founder, Joseph Calasanctius, was a Spanish priest in the $16^{\text {th }}$ century and his brotherhood was mostly focused on the education of the poor. With its network of schools spread across Central Europe, the Piarist catholic order had a dominant position in religious education during the $19^{\text {th }}$ century. As a part of the building complex, the Gymnasium Chapel of Saint Stephen (Szent Istvan) contains paintings dating from 1846 to 1879 that largely correspond to the current Central European tendencies of the second half of the $19^{\text {th }}$ century.

Patronage of the chapel is associated with the national identity crisis of the young European nations during the $19^{\text {th }}$ century. Dedicating the Chapel to the first Hungarian Christian monarch, 
Szent Istvan, the Hungarian nation constructs its national ideology through mythology and history, emphasizing the longevity of its tradition, rooted in Christian values. In addition to the main altar painted by József Wippler, depicting the figure of Szent Istvan, there are two side altars located in the south and north part of the Chapel. The south altar, painted by famous Hungarian artist József Peschky, depicts the founder of the Piarist order, Saint Joseph Calasanctius. As a leader of the Piarist brotherhood, Calasanctius had a noble mission of educating the poor. His contribution to religious education was notable and he became a patron saint of all catholic schools. The north altar depicts the copy of Raphael's Sistine Madonna by Josephus Lichtenegger and it conveys the ideas of the Nazarene circle that popularized the cult of Raphael across Central Europe during the $19^{\text {th }}$ century. A monumental fresco painting by Josef Goigner depicts scenes of the old and new testament following the templates of Gustave Dore's illustrated Bible. Paintings in the Piarist Gymnasium Chapel in Zrenjanin represent the ideas of Nazarene artists, as well as the principles of the Piarist order, which makes them a unique example of the sacral painting of $19^{\text {th }}$-century Central Europe.

Keywords: Piarist catholic order, religious painting, József Wippler, József Peschky, Josephus Lichtenegger, Josef Goigner. 